\title{
A Response to Emotional Intelligence and Clinical Performance of Undergraduate Nursing Students During Obstetrics and Gynaecology Nursing Practice. [Letter]
}

Vyshnavi Thanaraaj $\mathbb{D}$

Ahmed Turkman (D)

Imperial College London, Faculty of

Medicine, London, UK
Correspondence: Vyshnavi Thanaraaj Imperial College London, Faculty of Medicine, London, UK

Email vyshnavi.thanaraaj16@imperial.ac.uk

\section{Dear editor}

We read with great interest the article by Belay et $\mathrm{al}^{1}$ evaluating the association between Emotional Intelligence (EI) and clinical practice performance of undergraduate nursing students during obstetrics and gynaecology nursing practice. As final year medical students, we have engaged with teaching methods that enhance our EI and, therefore, acknowledge the significance of improving EI to maximise our clinical practice performance.

Belay et $\mathrm{al}^{1}$ assessed emotional intelligence using the Schutte Self report Emotional intelligence Test (SSEIT). This is a self-report method that the students used to evaluate their level of agreement with descriptive statements about their emotional abilities. However, Cherry et $\mathrm{al}^{2}$ determined that it is possible to see his or her compassion in action only by observing a person's communication. In addition, by self-reporting, the individual may lack appreciation of their emotional responses. Therefore, one way to improve this study is to engage with performancebased methods. ${ }^{3}$ This method allows us to examine how well the participants perform tasks and solve problems related to emotions, thus reducing prejudice and limiting the student from faking EI.

The aim of the study is to "develop higher EI in the accomplishment of the nursing program so as to increase the students' clinical performance". As previous studies have shown, emotional intelligence is made up of five clusters: self-awareness, selfregulation, motivation, empathy, and social skills. ${ }^{4}$ Self-awareness is believed to be the first trait to develop as an individual's EI grows, ${ }^{4}$ and this has also been shown to be the main lacking factor in many healthcare staff. ${ }^{5}$ Wilson ${ }^{5}$ illustrated that the nurses who were self-aware, for example, devising boundaries from their home and work life, assisted in managing the emotional stress they encountered at work. On the contrary, those unable to recognise the stressors, suffered from lack of sleep and intruding thoughts within their home life. Therefore, some workers were not informed of the concept of EI or how this could be employed in their work environment. The authors need to estimate the levels of self-awareness amongst the candidates from the results of the SSEIT, and if lacking, this is where their EI improvement would begin. We believe this would address the aims of the study more effectively. 
In conclusion, this study highlights the significance of developing EI to enhance clinical practice performance, further building nursing education in academic and clinical settings. In particular, the importance of healthcare workers to handle their own emotions while understanding and acknowledging others'. However, as previously discussed, studies have shown that the best way to assess EI is through performance-based methods and estimating the levels of self-awareness amongst the students. Therefore, we believe more emphasis should be placed on observational methods used to assess EI and identify the areas of improvement for the students.

\section{Disclosure}

The authors report no conflicts of interest for this communication.

\section{References}

1. Belay AS, Kassie A. Emotional intelligence and clinical performance of undergraduate nursing students during obstetrics and gynecology nursing practice; Mizan-Tepi University, South West Ethiopia. $A d v$ Med Educ Pract. 2021;12:913-922. doi:10.2147/AMEP.S325212

2. Cherry MG, Fletcher I, O'Sullivan H, Dornan T. Emotional intelligence in medical education: a critical review. Med Educ. 2014;48 (5):468-478. doi:10.1111/MEDU.12406

3. Hogeveen J, Salvi C, Grafman J. 'Emotional intelligence': lessons from lesions. Trends Neurosci. 2016;39(10):694. doi:10.1016/J. TINS.2016.08.007

4. Drigas AS, Papoutsi C. A new layered Model on emotional intelligence. Behav Sci (Basel). 2018;8(5):45. doi:10.3390/BS8050045

5. Wilson J, Wilson JL. The awareness of emotional intelligence by nurses and support workers in an acute hospital setting. Available from: http://shura.shu.ac.uk/9299/. Accessed September 1, 2021.

Dove Medical Press encourages responsible, free and frank academic debate. The content of the Advances in Medical Education and Practice 'letters to the editor' section does not necessarily represent the views of Dove Medical Press, its officers, agents, employees, related entities or the Advances in Medical Education and Practice editors. While all reasonable steps have been taken to confirm the content of each letter, Dove Medical Press accepts no liability in respect of the content of any letter, nor is it responsible for the content and accuracy of any letter to the editor.

\section{Publish your work in this journal}

Advances in Medical Education and Practice is an international, peerreviewed, open access journal that aims to present and publish research on Medical Education covering medical, dental, nursing and allied health care professional education. The journal covers undergraduate education, postgraduate training and continuing medical education including emerging trends and innovative models linking education, research, and health care services. The manuscript management system is completely online and includes a very quick and fair peer-review system. Visit http://www.dovepress.com/testimonials.php to read real quotes from published authors. 